\title{
Report on Chromosome Number Along with Chromosomal Chimera and Abnormal Shaped Anaphase of Acmella Ciliata
}

\author{
Riyad Hossen \\ Md. Uzzal Hossain \\ Lecturer, Department of Botany, Faculty of Biosciences, University of Barisal, \\ Bangladesh
}

This journal is licensed under a Creative Commons Attribution-NonCommercial 4.0 International License (CC-BY-NC). Articles can be read and shared for noncommercial purposes under the following conditions:

- BY: Attribution must be given to the original source (Attribution)

- NC: Works may not be used for commercial purposes (Noncommercial)

This license lets others remix, tweak, and build upon your work non-commercially, and although their new works must also acknowledge you and be non-commercial, they don't have to license their derivative works on the same terms. License Deed Link: http://creativecommons.org/licenses/by-nc/4.0/

Legal Code Link: http://creativecommons.org/licenses/by-nc/4.0/legalcode

$A B C$ Research Alert uses the CC BY-NC to protect the author's work from misuse.

\section{Abstract}

Acmella ciliata (Kunth) synomyme Spilanthes acmella Murr. is a plant species under asteraceae family is investigated cytogenetically by orcein staining to find out chromosome number, chimeric status and overall mitotic cell division. The diploid chromosome number $2 n=46$ was found in most of the cells but some cells possess $2 \mathrm{n}=70$ chromosomes in the same examined sample. So, we found two types cell according to their chromosome number which are indicated as type ' $a$ ' and ' $b$ '. The centromeric formulae of a type cell is $34 \mathrm{~m}+6 \mathrm{sm}$ while $52 \mathrm{~m}+18 \mathrm{sm}$ is for b type cells. The length of chromosomes range 3.68 to $2.30 \mu \mathrm{m}$ in a type cell and 3.68 to $2.24 \mu \mathrm{m}$ in b type cell that is approximately same in case of the length ranges. The total length of $2 \mathrm{n}$ chromosome complement of $b$ type cell is greater than a type cell. The variable chromosome number indicates its chromosomal chimera. No satellites were found. Some cell possesses abnormal anaphases which are clearly distinguishable to normal anaphase stages found in same species. Conventional karyotype analysis indicated that both type cell's chromosome number are totally different with previous report. Therefore, the compilation of the above cytogenetical information proves that the Acmella ciliata showing variable chromosome number means its chromosomal chimera. This cytogenetical information will help in the study of plant chromosomal chimera in Bangladesh.

\section{Keywords}

Karyotype, abnormal anaphase, Chimera, Acmella ciliata.

\section{INTRODUCTION}

Acmella ciliata, a medicinal plant belongs to the genus Acmella and belongs to the family Asteraceae (Fig. 1). In Bangladesh this species is synonymous with Spilanthes acmella Murr. and found throughout the country. They are generally annual or perennial herbs with 20-30 cm tall (Jansen et al). According to Chung et al. stems usually decumbent to ascending, rooting at nodes, green to purple, glabrous to sparsely pilose. Petioles $0.7-4 \mathrm{~cm}$ long, narrowly winged, glabrous or sparsely pilose, leaf blades ovate to broadly ovate, apex 
acute, margins denticulate to coarsely dentate, base usually truncate or cordate, glabrous to sparsely pilose on both sides, peduncles long and sparsely to moderately pilose. They also mentioned capitula radiate, solitary or 2 or 3, terminal or axillary, broadly ovoid, 6-10.5 mm high, 5.5-9.5 $\mathrm{mm}$ in diameter, involucral bracts 7-10, biseriate, outer series 3-5, narrowly to broadly ovate or elliptic, 4-6.9 $\times 1-2.3 \mathrm{~mm}$, inner series 3-6, lanceolate to ovate or elliptic, 2.8-6.1 $\times 1-2.9 \mathrm{~mm}$, receptacles 3.8-7.4 mm high, 0.8-1.9 mm in diameter, palea stramineous, 3-4.5 $\times$ 0.4-0.8 mm, ray florets, bisexual, corollas yellow orange, 2.5-6.5 mm long, tubes 0.9-2 $\mathrm{mm}$ long, limb 1.2-4.7 mm long, 1.1-3 mm wide. Besides ray florets, disc florets, bisexual, yellow-orange, corollas 5-merous, 1.5-2 mm long, tube 0.3-0.6 mm long, throat 1-1.5 mm long, lobes triangular, 0.2-0.4 $\times 0.2-$ $0.3 \mathrm{~mm}$. Furthermore, achenes black, 1.4-2.2 $\times 0.5-1 \mathrm{~mm}$, long, without shoulders, margins sparely to moderately ciliate with evident cork-like margins, pappus usually absent or sometimes of 2 very short subequal bristles less than $1 \mathrm{~mm}$ long also reported by them. They are native to northern South America and has naturalized in Celebes, India, Sumatra, and Thailand (Jansen, 1985). Richard (1807) described Acmella as a genus of five species that differ from species of Spilanthes in having ray florets and lack of pappus. Cassini in 1822 suggested that Acmella might be treated better as a section within Spilanthes. Acmella having 26 species described by De Candolle (1836). But Jansen (1981) provided convincing evidences for the recognition of Acmella and Spilanthes as distinct genera based on morphological, chromosomal and molecular evidences. Finally, Jansen transferred some of the taxa from Spilanthes to Acmella and recognized 30 species and 9 intraspecific taxa in Acmella. Chemical compound found such as palmitic and stearic acids, tetra-triacontanoic acid, sitosterol, stigmasterol and sitosterol glucoside and flower heads contain a local anesthetic amide, spilanthol and three other amides, a sterol, a non-reducing polysaccharide (Ghani, 2003). Acetic, lauric, myristic, linoleic and linolenic acid esters of $\alpha$ - and $\beta$-amyrin and myricyl alcohol have also been isolated from the plant (Rastogi \& Mehrotra, 1993). The species has tremendous medicinal importance such as treatment of toothaches, treat abrasions and distortions (Kasper, J. et al), analgesic (Rios, M.Y. et al.), anti-inflammatory ( $\mathrm{Wu}, \mathrm{L} . \mathrm{C}$. et al.) and antimalarial (Spelman, K. et al) in vitro activities, traditional African antimalarial drug "Malarial-5" (Gasquet, M. et al). Only a few earlier workers tried to find out only chromosome number and conventional karyotype but no report on this species about chromosomal chimera has been found. In cytogenetical study consistently possessing variable number of somatic chromosomes are referred as chromosomal chimera (Dontcho K.,1930). Some reports on this species revealed that the $2 \mathrm{n}$ chromosome number is 78 (Kuo-Fang Chung et al, Reshmi Geetha et al, etc). The basic chromosome number of this species is $\mathrm{X}=13$ (Jansen et al) and most of the species under this genus show polyploidy (Jansen et al, Reshmi Geetha et al, etc). Plant chromosomal chimeras were reported by various authors such as Lesley (1925) in Tomato and Crepis, Hollingshead (1928) in Crepis etc. Occasionally chimeras arise from loss or gain of individual chromosomes or chromosome fragments owing to misdivision and more commonly cytochimeras have simple multiple of the normal chromosome complement in the changed layer (Wikipedia). Besides, the occurrence of chromosomal chimera is the natural duplication of somatic chromosomes (H. B. Frost et al). Till now it cannot be determined when the duplication occurred, whether in a bud of the original parent tree or further back during its ontogeny, nor can it be determined how the differentiation into these two chimeras took place. Moreover, no report on mitotic abnormal shaped anaphase found in previous research work on this species. In Bangladesh enough, scientific works on this medicinally important plant are not available specially on cytogenetical and also cytological. Therefore, in the present study it has been carried out for the first time to detect the chromosomal chimera of Acmella ciliata found in Bangladesh.

\section{MATERIALS AND METHODS}

Acmella ciliata were collected from the several different locations of Curzon Hall, University of Dhaka, Bangladesh as a natural habitat. Then planted in researchable mud pot at room temperature served as the continuous sources of materials and for better observation and easily root collection. When it is desired to collect roots from plants growing in pots, care should be taken not to break the actively growing roots. Transfer roots to vials containing cold water after washing soil from the roots. Later, healthy roots were collected and pretreated with 8-hydroxyquinoline $(0.002 \mathrm{M})$ for 1.30 hour at $20-25^{\circ} \mathrm{C}$ followed by $15 \mathrm{~min}$ fixation in $45 \%$ acetic acid at $4{ }^{\circ} \mathrm{C}$. The pretreated RTs were hydrolyzed for 18-22s (depending on thickness of root) at $60^{\circ} \mathrm{C}$ in a mixture of $1 \mathrm{~N} \mathrm{HCl}$ and $45 \%$ acetic acid $(2: 1)$. The root tips were stained and squashed in $1 \%$ acetoorcein. And then the prepared slide is observed under Nikkon light microscope. Whole techniques are carried out by following Alam and Kondo orcein staining method. 


\section{RESULTS AND DISCUSSION}

Acmella ciliata were found to possesses $2 \mathrm{n}=46$ and 70 chromosomes more or less regularly (Figs. 2a, 2b) although the diploid chromosome number $2 \mathrm{n}=78$ for this species was reported earlier by Kuo-Fang Chung et al. No reports are available on this species about this type of chromosome number in their somatic cells. For avoiding the slide preparation errors, we examined more than 100 slide and each slide is prepared from individual root tips of the same sample. For confirmation of the findings we collected the roots from different times root cutting of the same sample. Every time we found same result. Besides, the somatic chromosome number at mitotic metaphase of this species some abnormal shaped anaphase was found along with normal shaped anaphases in every slide more or lessly of the all works (Fig. 4a, 4b) in our study. The abnormal shaped anaphases are same looking and clearly distinguishable from the normal one. Moreover, the chromosome length at mitotic metaphase varies gradually from about $3.68 \mu \mathrm{m}$ to about $2.30 \mu \mathrm{m}$ in a type cell and 3.68 to approximately $2.24 \mu \mathrm{m}$ found in $\mathrm{b}$ type cell $($ Table 1,2$)$ when we analyse the orcein karyotype of both type cell of the species. The total length of $2 \mathrm{n}$ chromosome complement is $133.15 \mu \mathrm{m}$ in a type cell whereas $200.53 \mu \mathrm{m}$ in $\mathrm{b}$ type cell which is clearly greater than a type cell. This is because $\mathrm{b}$ type cell holds more chromosomes than a type cell. The ' $a$ ' type cells showed centromeric formulae, i.e. $34 \mathrm{~m}+6 \mathrm{sm}$ and the centromeric formulae of b type cells is $52 \mathrm{~m}+18 \mathrm{sm}$ (Table 3 ). The range of all sm chromosomes of a type cells is $3.51 \mu \mathrm{m}$ to 2.65 and $\mathrm{b}$ type cells also show the same phenomenon in this sm chromosomes. No acrocentric or telocentric chromosomes are observed.
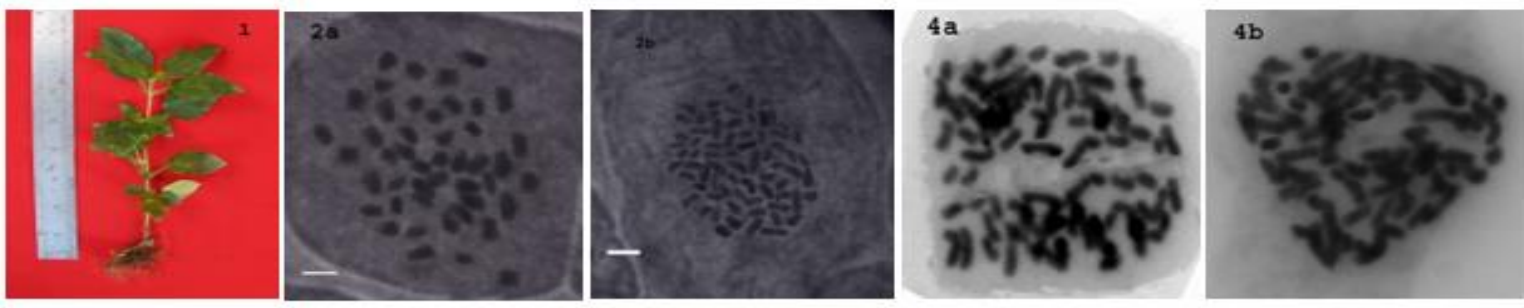

$\begin{array}{llll}3 a & 1 & 2\end{array}$

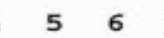

$\begin{array}{llll}10 & 11 & 12 & 13\end{array}$

$\begin{array}{lllll}14 & 15 & 16 & 17 & 18\end{array}$

$\begin{array}{lllll}19 & 20 & 21 & 22 & 23\end{array}$

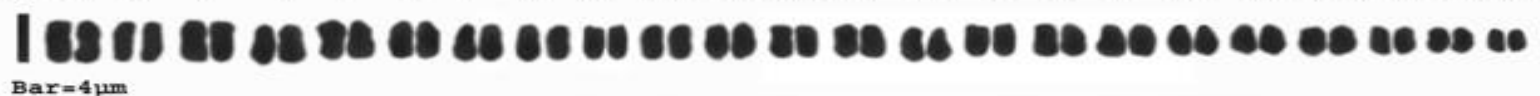

Bar $=4 \mu \mathrm{m}$

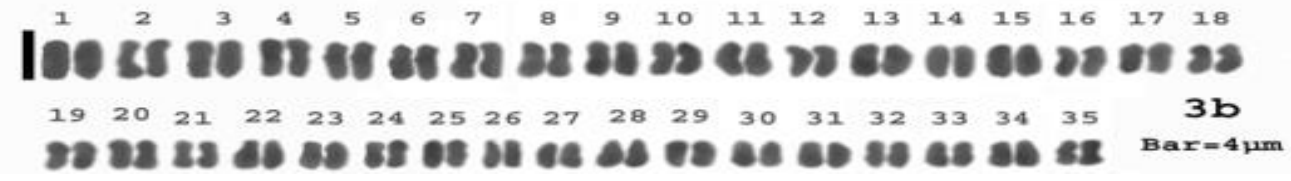

Fi Figures 1-4b. 1. Acmella ciliate (Kunth.) plant, 2a. Orcein-stained mitotic metaphase of a type cell, 2b. Orceinstained mitotic metaphase of $b$ type cell, 3a. Orcein-stained karyotype of a type cell, 3b. Orcein-stained karyotype of b type cell, $4 \mathrm{a}$. Orcein-stained irregular shaped anaphase stage and $4 \mathrm{~b}$. Orcein stained regular shaped anaphase stage. Bar indicates $4 \mu \mathrm{m}$.

\begin{tabular}{llllll}
\hline $\begin{array}{l}\text { Pair } \\
\text { No. }\end{array}$ & $\begin{array}{l}\text { Long arm } \\
(\boldsymbol{\mu m})\end{array}$ & $\begin{array}{l}\text { Short arm } \\
(\boldsymbol{\mu m})\end{array}$ & $\begin{array}{l}\text { Total length } \\
(\boldsymbol{\mu m})\end{array}$ & Arm ratio & CT \\
\hline $\mathbf{1}$ & 2.07 & 1.61 & 3.68 & 1.29 & $\mathbf{m}$ \\
& 2.02 & 1.61 & 3.68 & 1.29 & $\mathbf{m}$ \\
$\mathbf{2}$ & 2.13 & 1.50 & 3.62 & 1.42 & $\mathbf{m}$ \\
& 2.13 & 1.50 & 3.62 & 1.42 & $\mathbf{m}$ \\
$\mathbf{3}$ & 1.96 & 1.61 & 3.57 & 1.21 & $\mathbf{m}$ \\
& 1.96 & 1.61 & 3.57 & 1.21 & $\mathbf{m}$ \\
$\mathbf{4}$ & & & & & $\mathbf{s m}$ \\
& 2.30 & 1.21 & 3.51 & 1.90 & $\mathbf{s m}$ \\
$\mathbf{5}$ & 2.24 & 1.27 & 3.51 & 1.77 & $\mathbf{m}$ \\
& 1.73 & 1.67 & 3.39 & 1.03 & $\mathbf{m}$ \\
\hline
\end{tabular}




\begin{tabular}{|c|c|c|c|c|c|}
\hline \multirow[t]{2}{*}{6} & 1.73 & 1.67 & 3.39 & 1.03 & $\mathbf{m}$ \\
\hline & 1.73 & 1.50 & 3.22 & 1.15 & $\mathbf{m}$ \\
\hline \multirow[t]{2}{*}{7} & 1.73 & 1.50 & 3.22 & 1.15 & $\mathbf{m}$ \\
\hline & 1.78 & 1.44 & 3.22 & 1.24 & $\mathbf{m}$ \\
\hline \multirow[t]{2}{*}{8} & 2.01 & 1.09 & 3.11 & 1.84 & sm \\
\hline & 2.01 & 1.09 & 3.11 & 1.84 & $\mathrm{sm}$ \\
\hline \multirow[t]{2}{*}{9} & 2.13 & 0.86 & 2.99 & 2.47 & sm \\
\hline & 2.07 & 0.92 & 2.99 & 2.25 & $\mathrm{sm}$ \\
\hline \multirow[t]{2}{*}{10} & 1.96 & 0.98 & 2.93 & 2.00 & sm \\
\hline & 1.96 & 0.98 & 2.93 & 2.00 & $\mathrm{sm}$ \\
\hline \multirow[t]{2}{*}{11} & 1.61 & 1.21 & 2.82 & 1.33 & $\mathbf{m}$ \\
\hline & 1.61 & 1.21 & 2.82 & 1.33 & $\mathbf{m}$ \\
\hline \multirow[t]{2}{*}{12} & 1.55 & 1.21 & 2.76 & 1.29 & $\mathbf{m}$ \\
\hline & 1.55 & 1.21 & 2.76 & 1.29 & $\mathbf{m}$ \\
\hline \multirow[t]{2}{*}{13} & 1.84 & 0.86 & 2.70 & 2.13 & $\mathrm{sm}$ \\
\hline & 1.84 & 0.86 & 2.70 & 2.13 & $\mathrm{sm}$ \\
\hline \multirow[t]{2}{*}{14} & 1.84 & 0.86 & 2.70 & 2.13 & sm \\
\hline & 1.78 & 0.86 & 2.65 & 2.07 & sm \\
\hline \multirow[t]{2}{*}{15} & 1.44 & 1.21 & 2.65 & 1.19 & $\mathbf{m}$ \\
\hline & 1.38 & 1.27 & 2.65 & 1.09 & $\mathbf{m}$ \\
\hline \multirow[t]{2}{*}{16} & 1.38 & 1.21 & 2.59 & 1.14 & $\mathbf{m}$ \\
\hline & 1.38 & 1.21 & 2.59 & 1.14 & $\mathbf{m}$ \\
\hline \multirow[t]{2}{*}{17} & 1.44 & 1.15 & 2.59 & 1.25 & $\mathbf{m}$ \\
\hline & 1.44 & 1.15 & 2.59 & 1.25 & $\mathbf{m}$ \\
\hline \multirow[t]{2}{*}{18} & 1.38 & 1.09 & 2.47 & 1.26 & $\mathbf{m}$ \\
\hline & 1.38 & 1.09 & 2.47 & 1.26 & $\mathbf{m}$ \\
\hline \multirow[t]{2}{*}{19} & 1.38 & 1.09 & 2.47 & 1.26 & $\mathbf{m}$ \\
\hline & 1.38 & 1.09 & 2.47 & 1.26 & $\mathbf{m}$ \\
\hline \multirow[t]{2}{*}{20} & 1.38 & 1.09 & 2.47 & 1.26 & $\mathbf{m}$ \\
\hline & 1.32 & 1.09 & 2.42 & 1.21 & $\mathbf{m}$ \\
\hline \multirow[t]{2}{*}{21} & 1.32 & 1.09 & 2.42 & 1.21 & $\mathbf{m}$ \\
\hline & 1.32 & 1.09 & 2.42 & 1.21 & $\mathbf{m}$ \\
\hline \multirow[t]{2}{*}{22} & 1.27 & 1.09 & 2.36 & 1.16 & $\mathbf{m}$ \\
\hline & 1.27 & 1.09 & 2.36 & 1.16 & $\mathbf{m}$ \\
\hline \multirow[t]{4}{*}{23} & 1.27 & 1.04 & 2.30 & 1.22 & $\mathbf{m}$ \\
\hline & 1.27 & 1.04 & 2.30 & 1.22 & $\mathbf{m}$ \\
\hline & & & Total & & \\
\hline & & & 133.15 & & \\
\hline
\end{tabular}

Table 1: Length (in $\mu \mathrm{m}$ ), arm ratio, relative and centromeric type of metaphase chromosomes of a type cell of Acmella ciliata $\mathrm{m}=$ metacentric chromosome, $\mathrm{sm}=$ submetacentric chromosome, $\mathrm{CT}=$ Centromeric type 


\begin{tabular}{|c|c|c|c|c|c|}
\hline $\begin{array}{r}\text { Pair } \\
\text { No. }\end{array}$ & $\begin{array}{l}\text { Longarm } \\
(\mu \mathrm{m})\end{array}$ & $\begin{array}{l}\text { Short arm } \\
(\mu \mathrm{m})\end{array}$ & $\begin{array}{l}\text { Total length } \\
(\mu \mathrm{m})\end{array}$ & Arm ratio & $\mathrm{CT}$ \\
\hline \multirow[t]{2}{*}{1} & 2.01 & 1.67 & 3.68 & 1.21 & $\mathbf{m}$ \\
\hline & 2.01 & 1.67 & 3.68 & 1.21 & $\mathbf{m}$ \\
\hline \multirow[t]{2}{*}{2} & 2.19 & 1.50 & 3.68 & 1.46 & $\mathbf{m}$ \\
\hline & 2.19 & 1.50 & 3.68 & 1.46 & $\mathbf{m}$ \\
\hline \multirow[t]{2}{*}{3} & 1.90 & 1.67 & 3.57 & 1.14 & $\mathbf{m}$ \\
\hline & 1.90 & 1.61 & 3.57 & 1.21 & $\mathbf{m}$ \\
\hline \multirow[t]{2}{*}{4} & 2.04 & 1.50 & 3.57 & 1.38 & $\mathbf{m}$ \\
\hline & 2.04 & 1.50 & 3.57 & 1.38 & $\mathbf{m}$ \\
\hline \multirow[t]{2}{*}{5} & 2.24 & 1.27 & 3.51 & 1.77 & sm \\
\hline & 2.24 & 1.27 & 3.51 & 1.77 & sm \\
\hline \multirow[t]{2}{*}{6} & 2.13 & 1.38 & 3.51 & 1.54 & sm \\
\hline & 2.13 & 1.38 & 3.51 & 1.54 & sm \\
\hline \multirow[t]{2}{*}{7} & 2.01 & 1.38 & 3.39 & 1.46 & $\mathbf{m}$ \\
\hline & 2.01 & 1.38 & 3.39 & 1.46 & $\mathbf{m}$ \\
\hline \multirow[t]{2}{*}{8} & 1.78 & 1.55 & 3.34 & 1.15 & $\mathbf{m}$ \\
\hline & 1.78 & 1.55 & 3.34 & 1.15 & $\mathbf{m}$ \\
\hline \multirow[t]{2}{*}{9} & 1.73 & 1.50 & 3.22 & 1.15 & $\mathbf{m}$ \\
\hline & 1.73 & 1.50 & 3.22 & 1.15 & $\mathbf{m}$ \\
\hline \multirow[t]{2}{*}{10} & 1.90 & 1.32 & 3.22 & 1.43 & $\mathbf{m}$ \\
\hline & 1.84 & 1.32 & 3.16 & 1.39 & $\mathbf{m}$ \\
\hline \multirow[t]{2}{*}{11} & 2.07 & 1.04 & 3.11 & 2.00 & sm \\
\hline & 2.07 & 1.04 & 3.11 & 2.00 & sm \\
\hline \multirow[t]{2}{*}{12} & 2.07 & 1.04 & 3.11 & 2.00 & sm \\
\hline & 2.07 & 0.98 & 3.05 & 2.12 & $\mathrm{sm}$ \\
\hline \multirow[t]{2}{*}{13} & 1.84 & 1.15 & 2.99 & 1.60 & sm \\
\hline & 1.84 & 1.15 & 2.99 & 1.60 & sm \\
\hline \multirow[t]{2}{*}{14} & 1.90 & 1.04 & 2.93 & 1.83 & sm \\
\hline & 1.90 & 1.04 & 2.93 & 1.83 & sm \\
\hline \multirow[t]{2}{*}{15} & 1.90 & 1.04 & 2.93 & 1.83 & sm \\
\hline & 1.84 & 1.04 & 2.88 & 1.78 & sm \\
\hline \multirow[t]{2}{*}{16} & 1.67 & 1.15 & 2.82 & 1.45 & $\mathbf{m}$ \\
\hline & 1.67 & 1.15 & 2.82 & 1.45 & $\mathbf{m}$ \\
\hline \multirow[t]{2}{*}{17} & 1.55 & 1.27 & 2.82 & 1.23 & $\mathbf{m}$ \\
\hline & 1.50 & 1.27 & 2.76 & 1.18 & $\mathbf{m}$ \\
\hline \multirow[t]{2}{*}{18} & 1.61 & 1.15 & 2.76 & 1.40 & $\mathbf{m}$ \\
\hline & 1.61 & 1.15 & 2.76 & 1.40 & $\mathbf{m}$ \\
\hline \multirow[t]{2}{*}{19} & 1.44 & 1.27 & 2.70 & 1.14 & $\mathbf{m}$ \\
\hline & 1.44 & 1.27 & 2.70 & 1.14 & $\mathbf{m}$ \\
\hline \multirow[t]{2}{*}{20} & 1.78 & 0.92 & 2.70 & 1.94 & sm \\
\hline & 1.78 & 0.92 & 2.70 & 1.94 & $\mathrm{sm}$ \\
\hline \multirow[t]{2}{*}{21} & 1.61 & 1.04 & 2.65 & 1.56 & $\mathrm{sm}$ \\
\hline & 1.61 & 1.04 & 2.65 & 1.56 & sm \\
\hline \multirow[t]{2}{*}{22} & 1.55 & 1.09 & 2.65 & 1.42 & $\mathbf{m}$ \\
\hline & 1.50 & 1.15 & 2.65 & 1.30 & $\mathbf{m}$ \\
\hline
\end{tabular}




\begin{tabular}{|c|c|c|c|c|c|}
\hline 23 & $\begin{array}{l}1.44 \\
1.44\end{array}$ & $\begin{array}{l}1.15 \\
1.15\end{array}$ & $\begin{array}{l}2.59 \\
2.59\end{array}$ & $\begin{array}{l}1.25 \\
1.25\end{array}$ & $\begin{array}{l}\mathrm{m} \\
\mathrm{m}\end{array}$ \\
\hline 24 & $\begin{array}{l}1.44 \\
1.38\end{array}$ & $\begin{array}{l}1.15 \\
1.21\end{array}$ & $\begin{array}{l}2.59 \\
2.59\end{array}$ & $\begin{array}{l}1.25 \\
1.14\end{array}$ & $\begin{array}{l}\mathrm{m} \\
\mathrm{m}\end{array}$ \\
\hline 25 & $\begin{array}{l}1.38 \\
1.38\end{array}$ & $\begin{array}{l}1.15 \\
1.15\end{array}$ & $\begin{array}{l}2.53 \\
2.53\end{array}$ & $\begin{array}{l}1.20 \\
1.20\end{array}$ & $\begin{array}{l}\mathbf{m} \\
\mathbf{m}\end{array}$ \\
\hline 26 & $\begin{array}{l}1.44 \\
1.50\end{array}$ & $\begin{array}{l}1.09 \\
1.04\end{array}$ & $\begin{array}{l}2.53 \\
2.53\end{array}$ & $\begin{array}{l}1.32 \\
1.44\end{array}$ & $\begin{array}{l}\mathrm{m} \\
\mathrm{m}\end{array}$ \\
\hline 27 & $\begin{array}{l}1.38 \\
1.32\end{array}$ & $\begin{array}{l}1.09 \\
1.15\end{array}$ & $\begin{array}{l}2.47 \\
2.47\end{array}$ & $\begin{array}{l}1.26 \\
1.15\end{array}$ & $\begin{array}{l}\mathbf{m} \\
\mathbf{m}\end{array}$ \\
\hline 28 & $\begin{array}{l}1.27 \\
1.27\end{array}$ & $\begin{array}{l}1.21 \\
1.21\end{array}$ & $\begin{array}{l}2.47 \\
2.47\end{array}$ & $\begin{array}{l}1.05 \\
1.05\end{array}$ & $\begin{array}{l}\mathrm{m} \\
\mathrm{m}\end{array}$ \\
\hline 29 & $\begin{array}{l}1.32 \\
1.38\end{array}$ & $\begin{array}{l}1.09 \\
1.04\end{array}$ & $\begin{array}{l}2.42 \\
2.42\end{array}$ & $\begin{array}{l}1.21 \\
1.33\end{array}$ & $\begin{array}{l}\mathrm{m} \\
\mathrm{m}\end{array}$ \\
\hline 30 & $\begin{array}{l}1.32 \\
1.38\end{array}$ & $\begin{array}{l}1.09 \\
1.04\end{array}$ & $\begin{array}{l}2.42 \\
2.42\end{array}$ & $\begin{array}{l}1.21 \\
1.33\end{array}$ & $\begin{array}{l}\mathrm{m} \\
\mathrm{m}\end{array}$ \\
\hline 31 & $\begin{array}{l}1.27 \\
1.21\end{array}$ & $\begin{array}{l}1.09 \\
1.15\end{array}$ & $\begin{array}{l}2.36 \\
2.36\end{array}$ & $\begin{array}{l}1.16 \\
1.05\end{array}$ & $\begin{array}{l}\mathbf{m} \\
\mathbf{m}\end{array}$ \\
\hline 32 & $\begin{array}{l}1.21 \\
1.21\end{array}$ & $\begin{array}{l}1.15 \\
1.09\end{array}$ & $\begin{array}{l}2.36 \\
2.30\end{array}$ & $\begin{array}{l}1.05 \\
1.11\end{array}$ & $\begin{array}{l}\mathrm{m} \\
\mathrm{m}\end{array}$ \\
\hline 33 & $\begin{array}{l}1.27 \\
1.27\end{array}$ & $\begin{array}{l}1.04 \\
1.04\end{array}$ & $\begin{array}{l}2.30 \\
2.30\end{array}$ & $\begin{array}{l}1.22 \\
1.22\end{array}$ & $\begin{array}{l}\mathrm{m} \\
\mathrm{m}\end{array}$ \\
\hline 34 & $\begin{array}{l}1.21 \\
1.15\end{array}$ & $\begin{array}{l}1.09 \\
1.09\end{array}$ & $\begin{array}{l}2.30 \\
2.24\end{array}$ & $\begin{array}{l}1.11 \\
1.05\end{array}$ & $\begin{array}{l}\mathrm{m} \\
\mathrm{m}\end{array}$ \\
\hline 35 & $\begin{array}{l}1.21 \\
1.21\end{array}$ & $\begin{array}{l}1.04 \\
1.04\end{array}$ & $\begin{array}{l}2.24 \\
2.24 \\
\text { Total }\end{array}$ & $\begin{array}{l}1.17 \\
1.17\end{array}$ & $\begin{array}{l}\mathrm{m} \\
\mathrm{m}\end{array}$ \\
\hline & & & 200.53 & & \\
\hline
\end{tabular}

Table 2: Length (in $\mu \mathrm{m}$ ), arm ratio, relative length and centromeric type of metaphase chromosomes of $\mathrm{b}$ type cell of Acmella ciliata $\mathrm{m}=$ metacentric chromosome, $\mathrm{sm}=$ submetacentric chromosome, $\mathrm{CT}=$ Centromeric type

\begin{tabular}{lcccc}
\hline Cell type & $\mathbf{2 n}$ & $\begin{array}{c}\text { Range of chro- } \\
\text { mosomal } \\
\text { length }(\boldsymbol{\mu m})\end{array}$ & $\begin{array}{c}\text { Totallength of 2n } \\
\text { chromosome com- } \\
\text { plements }(\boldsymbol{\mu m})\end{array}$ & $\begin{array}{c}\text { Centromeric formu- } \\
\text { lae }\end{array}$ \\
\hline Type a & 46 & $3.68-2.30$ & 133.15 & $34 \mathrm{~m}+12 \mathrm{sm}$ \\
Type b & 70 & $3.68-2.24$ & 200.53 & $52 \mathrm{~m}+18 \mathrm{sm}$ \\
\hline
\end{tabular}

Table 3: Comparative karyotype analysis of two types cell of Acmella ciliata.

Therefore, the plant Acmella ciliata found in Bangladesh having new chromosome numbers with abnormal anaphase and the probable chromosomal chimera report is not similar to the previous reports of chromosome number $2 \mathrm{n}=78$. The species, in respect of centromeric formulae, karyotype analysis and also for the variable chromosome number of both type cells indicates about the chromosomal chimera and new chromosome number (Fig. 3a, 3b). Furthermore, the results indicated that Acmella ciliata with somatic chromosome number $2 \mathrm{n}=46$ and 70 show chromosomal chimeric nature of its somatic cells. But in this article, we don't mention how the chimera occurred or created. We just found it by tracking mitotic metaphase. Only we assumed that he abnormal shaped anaphases is may be linked with the occurrence of the chromosomal chimera as well as new chromosome numbers. In our study no satellites were observed. The observed abnormal shaped anaphase demonstrates the probable three poles(Fig.4b) in the dividing cell whereas the regular shaped anaphase contains two poles(Fig.4a). 


\section{CONCLUSION}

No previous report has been found about similar with the $2 n=46,70$ chromosomes number, chromosome chimera, abnormal anaphase so this is probably the new report about the chromosome number of the species and also the first report on chromosomal chimera of the species from Bangladesh.

\section{Acknowledgements}

This research was supported by Cytogenetics Lab. department of Botany, University of Dhaka and Chromosome Research Centre, University of Dhaka, Bangladesh. Also supported by the dept. of Botany, University of Barisal, Bangladesh.

\section{References}

Alam, Sk. S. and Kondo, K. (1995) Differential staining with Orcein, Giemsa, CMA, and DAPI for comparative chromosome study of 12 species of Australian Drosera (Droseraceae). Am. J. Bot., 82, 1278-1286.

Althaus, J.B., Kaiser, M., Brun, R., Schmidt, T. J. (2014) Antiprotozoal activity of Achillea ptarmica (Asteraceae) and its main alkamide constituents. Molecules, 19, 6428-6438.

Chung, K., Kono, Y., WANG, C., and Peng, C. (2008) Notes on Acmella (Asteraceae: Heliantheae) in Taiwan. Botanical Studies, $49,73-82$.

De Candolle, A. P. (1836) Spilanthes. In: De Candolle AP (ed) Prodromus systematis naturalis regni vegetables. Treuttel and Wurtz, Paris, 5, 620-626.

Frost, H. B. and Krug, C. A. (1942) Diploid-tetraploid periclinal chimeras as bud variations in Citrus. Genetics, 27, 619-634.

Gasquet, M., Delmas, F., Timon-David, P., Keita, A., Guindo, M., Koita, N., Diallo, D., Doumbo, O. (1993) Evaluation in vitro and in vivo of a traditional antimalarial, "Malarial 5". Fitoterapia, 64, 423- 426.

Ghani, A. (2003) Medicinal plants of Bangladesh with chemical constituents and uses. Asiatic Society of Bangladesh, Dhaka, 2, 184

Jansen, R. K. (1981) Systematics of Spilanthes (Compositae: Heliantheae). Syst. Bot., 6, 231-257.

Jansen, R. K. (1985) The systematics of Acmella (Asteraceae-Heliantheae). Syst. Bot. Monogr., 8, 1-115.

Kasper, J., Melzig, M. F., Jenett-Siems, K. (2010) New phenolic compounds of Acmella ciliata. Planta. Med., 76, 633-635.

Kostoff , D. (1930) A Chromosomal Chimera in Tobacco: Somatic Non-Disjunction and Doubling of Chromosomes in a Nicotiana Hybrid. J. of Heredity, 21, 445-448.

Rastogi, R. P., Mehrotra, B. N. (1993) Compendium of Indian medicinal plants, Vol-II, CDRI Lucknow, Publication and information Directorate, New Delhi, India.

Richard, L. C. (1807) Acmella: In Synopsis Plantarum, by C. Persoon, Paris, 42, 472-473.

Rios, M. Y., Guadarrama, A. B. A., Gutiérrez, M. C. (2007) Analgesic activity of affinin, an alkamide from Heliopsis longipes (Compositae). J. Ethnopharmacol., 110, 364-367.

Spelman, K., Depoix, D., McCray, M., Mouray, E., Grellier, P. (2011) The traditional medicine Spilanthes acmella and the alkylamides spilanthol and undeca-2E-ene-8,10-diynoic acid isobutylamide, demonstrate in vitro and in vivo antimalarial activity. Phytother. Res,. 25, 1098-1101.

Wu, L. C., Fan, N. C., Lin, M. H., Chu, I. R., Huang, H. J., Hu, C. Y., Han, S. Y. (2008) Anti-inflammatory effect of spilanthol from Spilanthes acmella on murine macrophage by down-regulating LPS-induced inflammatory mediators. J. Agric. Food Chem., 56, 2341-2349. 